\title{
Pendampingan Pengelolaan Keuangan Desa Guna Meningkatkan Akuntabilitas di Desa Mlandi Wonosobo
}

\author{
Desy Nur Pratiwi*, Dewi Muliasari \\ Prodi Akuntansi Institut Teknologi Bisnis AAS Indonesia \\ J1. Slamet Riyadi No 361, Windan, Makamhaji, Kartasura, Sukoharjo, Jawa Tengah \\ *E-mail : desynurpratiwi@itbaas.ac.id \\ DOI: https://doi.org/10.21107/pangabdhi.v6i2.7506 \\ Naskah diterima 4 Agustus 2020, Revisi 7 September 2020, Terbit 29 Oktober 2020
}

\begin{abstract}
Abstrak
Tujuan dari penyelenggaraan kegiatan pelatihan pengelolaan keuangan desa yaitu untuk memberikan pengetahuan yang memadai tentang pelaporan keuangan desa sesuai dengan standar akuntansi yang berlaku dan memberikan pelatihan penyusunan laporan keuangan desa. Kegiatan pengabdian dilaksanakan pada bulan Februari 2020 di Desa Mlandi, Kec. Gerung, Wonosobo. Pelatihan diikuti oleh 10 peserta, meliputi kepala desa, sekretaris desa, bendahara, kasi, kaur, pendamping, tenaga administrasi dan perwakilan masyarakat. Metode yang digunakan dalam kegiatan pelatihan yaitu ceramah, tutorial dan diskusi. Kegiatan pelatihan berjalan lancar dan para peserta antusias dalam mengikuti materi. Masyarakat juga merasakan pentingnya pelatihan ini karena akan meningkatkan akuntabilitas dalam pengelolaan keuangan desa.
\end{abstract}

Kata Kunci: keuangan desa; laporan keuangan; standar akuntansi

\begin{abstract}
The aim of conducting village financial management training activities is to provide adequate knowledge of village financial reporting in accordance with applicable accounting standards and to provide training in the preparation of village financial statements. Community service activities were held on February 2020 in Mlandi Village, Sub-district Gerung, Wonosobo. The training was attended by 10 participants, including the head village, the secretary, treasurer, head of office, staff, assistants, administrative staff and community representatives. The methods used in training activities are lectures, tutorials and discussions. The training activities went well and the participants were enthusiastic in following the material. The community also felt the importance of this training because it would increase accountability in village financial management.
\end{abstract}

Keywords: village finance; financial statements; accounting standard

\section{PENDAHULUAN}

Pemerintah memberikan bantuan dana desa untuk semua desa yang ada di Indonesia sejak 2015. Dana desa yang diberikan oleh pemerintah bertujuan agar desa menjadi lebih produktif dan meningkatkan kesejahteraan masyarakat desa. Peningkatan produktivitas desa ini dilihat dari perkembangan ekonominya meningkat, jumlah masyarakat yang bekerja dan memiliki usaha bertambah, kualitas hidup menjadi lebih baik. Salah satu sumber penerimaan desa yaitu dana perimbangan keuangan pusat dan daerah yang diterima oleh kabupaten/kota yang dalam pembagiannya untuk setiap desa dibagikan secara proporsional yaitu paling sedikit $10 \%$ yang disebut dengan alokasi dana desa. Selanjutnya, anggaran alokasi dana desa tersebut akan digunakan sebagai penunjang kegiatan otonomi desa agar dapat maksimal dalam memberikan pelayanan, pembangunan, serta pemberdayaan masyarakat ditingkat pedesaan. Oleh karena itu, jika anggaran tersebut dikelola secara baik dan jujur maka hasil kegiatan otonomi desa, khususnya pemberdayaan masyarakat akan terlihat jelas.

Dana desa perlu pengawalan dari berbagai pihak agar berjalan sesuai dengan tujuannya. Jika pengawalan atau pendampingan ini tidak dilakukan maka dikhawatirkan akan muncul berbagai permasalahan mulai dari perencanaan, 
pengelolaan, pengawasan hingga pelaporannya. Munculnya beberapa kekhawatiran di desa Mlandi terkait dengan pengelolaan dana desa bagi pengelolanya misalnya: kesiapan sumber daya manusia (SDM) dalam menjalankan program yang telah direncanakan, pemahaman bagaimana mengelola atau menggunakan dana desa tidak sama antara satu desa dengan desa lainnya. Jika hal ini dibiarkan maka potensi pengelolaan atau penggunaan dana desa tidak dapat mencapai tujuan sesuai keinginan pemerintah. Permasalahan pada tahap pelaporan keuangan dana desa sendiri dinilai masih membingungkan karena dana desa ini baru turun tahap pertama di bulan April 2015. Apabila SDM di desa tidak menguasai pelaporan keuangan maka pada akhir tahun 2015 maka akan muncul banyak keluhan dari desa terkait dengan pelaporan keuangan dana desa.

Menurut Mardiasmo (2002) akuntabilitas adalah kewajiban pihak pemegang amanah untuk memberikan pertanggungjawaban, menyajikan dan mengungkapkan segala aktivitasnya dan kegiatan yang menjadi tanggungjawabnya kepada pihak pemberi amanah (principal) yang memiliki hak dan kewenangan untuk meminta pertanggungjawaban tersebut. Pemerintah Kota Kotamobagu merupakan salah satu daerah otonom yang ada di Provinsi Sulawesi Utara yang telah melaksanakan prinsip-prinsip otonomi daerah dengan berusaha mengoptimalkan potensi desa dengan mengalokasikan dana desa dalam APBD yang bersumber dari APBN.

Akuntabilitas merupakan hal yang penting karena dengan keterbukaan informasi keuangan bagi masyarakat maka masyarakat mampu menilai kinerja perangkat desa. Hasil penelitian Hanifah \& Praptoyo (2015) menunjukkan bahwa pengelolan Keuangan Desa di Kabupaten Jombang secara garis besar pengelolaan Keuangan Desa telah mencapai akuntabilitas, namun masih diperlukan adanya pendampingan desa dari pemerintah daerah yang intensif dalam membantu desa untuk mewujudkan akuntabilitas pengelolaan keuangan Desa. Namun berbeda dengan hasil penelitian Istiqomah (2015) menunjukkan efektivitas kinerja Badan Permusyawaratan Desa (BPD) menunjukkan hasil kerja yang kurang efektif dimana terlihat dari ketiga fungsinya baik itu legislasi, anggaran dan pengawasan yang masih kurang, sehingga pengelolaan alokasi dana desa kurang akuntabel.

Desa banyak mengalami kendala dalam pengelolaan keuangan desa. Hal ini dibuktikan oleh hasil penelitian Wida et al., (2017) menunjukkan tahap pertanggungjawaban pengelolaan dana desa belum berjalan dengan baik dikarenakan Sumber Daya Manusia tim pelaksana dalam membuat laporan administrasi yang masih kurang, sehingga diperlukan adanya pembinaan dan pengawasan lebih dari pemerintah daerah. Sejalan dengan Kholmi (2016); hasil penelitian Diansari (2015) menunjukkan kurangnya pemahaman aparatur desa dalam mengimplementasikan alokasi dana desa.

Husna \& Abdullah (2016) menyatakan bahwa kendala yang dialami aparatur desa yaitu kurangnya sumber daya manusia yang handal dan faham mengenai pengelolaan keuangan desa. Dari hasil survey tersebut menunjukan masih diperlukan pembinaan dan pengawasan agar tercapai tata kelola desa yang baik. Hal ini sejalan penelitian Hanifah \& Praptoyo (2015) bahwa masih banyak hambatan dalam pengelolaan keuangan desa karena belum efektifnya pelatihan para perangkat desa dan kompetensi sumber daya manusia, sehingga masih memerlukan perhatian khusus dari aparat pemerintah desa secara berkelanjutan. Namun berbeda dengan penelitian Astini et al., (2019) bahwa kualitas sumber daya manusia tidak berpengaruh signifikan terhadap keberhasilan pengelolaan keuangan desa.

Desa Mlandi merupakan sebuah desa yang terletak di Kecamatan Garung, Kabupaten Wonosobo, Jawa Tengah, Indonesia. Desa ini berjarak sekira $3 \mathrm{Km}$ dari ibu kota kecamatan. Setelah melakukan survey di desa Mlandi, abdimas mengetahui bahwa Kepala desa dan perangkatnya mempunyai tugas berat dalam menjalankan roda pemerintahan di tingkat desa. Saat ini, Desa dituntut mampu mengelola anggaran pemerintah yang nilainya cukup besar, Sehingga Kades dan perangkatnya mesti lebih meningkatkan kapasitas Sumber Daya Manusia (SDM) dengan berbagai kegiatan pelatihan ataupun bimbingan teknis (Bimtek). Termasuk kegiatan peningkatan SDM aparatur desa ini dinilai sangat membantu dalam peningkatan kapasitas dan kemampuan perangkat desa.

Berdasarkan latar belakang tersebut, maka dilakukanlah pendampingan pengelolaan keuangan desa di desa Mlandi bertujuan untuk :

1. Dengan adanya pelatihan ini maka diharapkan pemerintah desa dapat menjalankan amanah dan menjaga kepercayaan publik. 
2. Diharapkan dapat terjalin kerja sama yang semakin erat di masa mendatang, sehingga dapat memberikan kontribusi positif pada kedua belah pihak

3. Memberikan pengetahuan yang memadai mengenai pelaporan keuangan Dana Desa dan Memberikan pelatihan untuk membuat laporan keuangan Dana Desa.

\section{METODE}

Tim pengabdian melakukan sosialisasi kepada pengelola keuangan desa merupakan langkah awal dalam proses pendekatan agar tujuan mudah tercapai. Dengan adanya sosialisasi tersebut akan terjalin hubungan baik yang dilandasi oleh kepentingan yang sama yaitu meningkatkan pemahaman dan kemampuan menyusun laporan keuangan desa. Tim melakukan koordinasi dengan kepala desa Mlandi Kec. Gerung, Wonosobo untuk menanyakan apa pelatihan yang dibutuhkan bagi desa tersebut. Salah satu hal yang dibutuhkan desa Mlandi dan sesuai bidang ilmu tim yaitu pengelola keuangan desa masih belum mampu menyusun laporan keuangan sesuai standar.

Program pelatihan pengelolaan keuangan desa dilaksanakan di Desa Mlandi, Kec. Garung, Wonosobo pada Sabtu, 15 Februari 2020 dengan jadwal pelaksanaan kegiatan sesuai kesepakatan pemerintah desa tersebut. Pelaksanaan kegiatan pengabdian ini dilakukan dengan beberapa metode, yaitu:

\section{- Ceramah}

Metode ini memberikan penjelasan kepada para peserta tentang peraturan dan standar dalam pengelolaan keuangan desa. Selain itu, peserta juga dikenalkan berbagai macam bentuk laporan keuangan dan mengenal pentingnya menyusun laporan keuangan desa sebagai bentuk akuntabilitas kepada masyarakat desa. Metode ceramah ini dilakukan selama 1,5 jam. Media yang digunakan untuk membantu kelancaran presentasi yaitu laptop dan LCD Proyektor.

\section{- $\underline{\text { Tutorial }}$}

Peserta pelatihan diberikan materi tentang tahapan penyiapan dokumen untuk mempersiapkan penyusunan laporan keuangan. Selain itu, peserta juga diberikan contoh kasus serta tahapan dalam menyusun laporan keuangan. Tahap kedua ini dilakukaan selama 3 jam. Media yang mendukung dalam mempraktikan penyusunan laporan keuangan yaitu Ms. Excel.
- $\underline{\text { Diskusi }}$

Peserta diberikan kesempatan untuk mendiskusikan permasalahan yang berkaitan dengan penyusunan laporan keuangan dan kesulitan yang mereka alami. Tahap ketiga ini dilakukan selama 1 jam. Media yang mendukung saat diskusi yaitu whiteboard dan spidol.

\section{- $\quad$ Pendampingan}

Langkah ini merupakan hal yang paling penting karena peserta didampingi dalam penyusunan laporan keuangan desa sampai mereka paham. Tahap keempat dilakukan selama 3 jam. Media yang sangat penting saat melaksanakan pendapingan yaitu kertas berisi contoh-contoh penyusunan laporan keuangan desa.

\section{HASIL DAN PEMBAHASAN}

Kegiatan pelatihan pengelolaan keuangan desa dilakukan diruang rapat desa Mlandi, Kec. Garung, Wonosobo berjalan lancar. Kegiatan tersebut diawali dengan pembukaan Budi Irawan sebagai kepada desa. Sesi pertama, dimulai dengan materi pengantar pengelolaan keuangan desa. Pada sesi ini peserta diberikan materi aturan sebelum dan sesudah adanya undangundang terbaru terntang desa. Selain itu, materi pada sesi pertama juga membahas penyusunan anggaran desa.
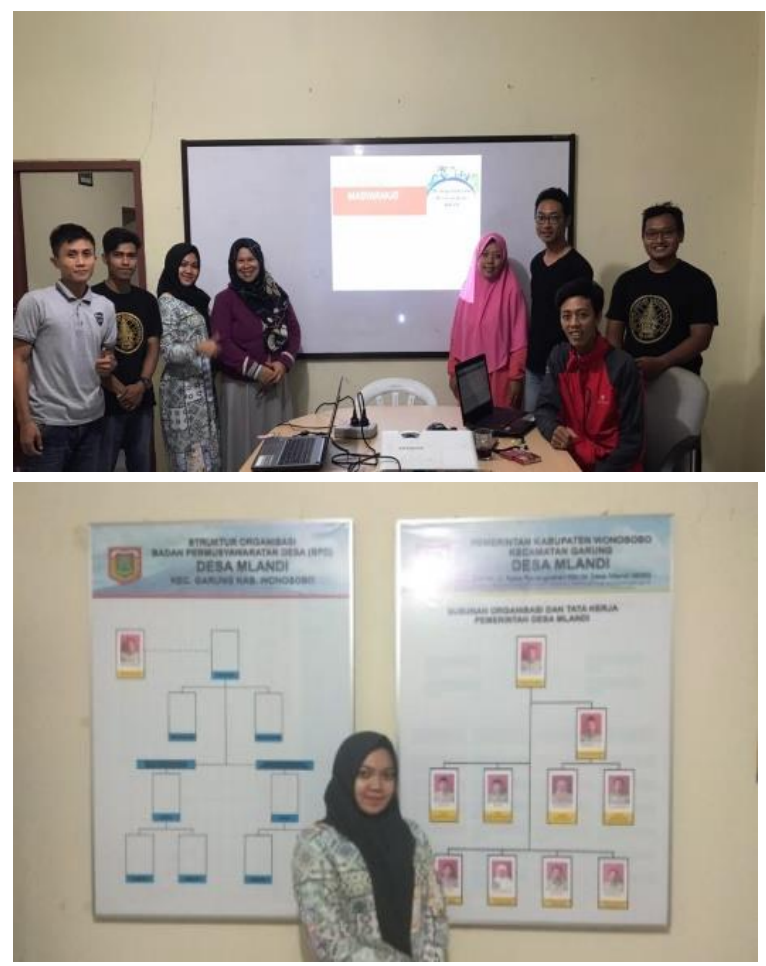

Gambar 1. Dokumentasi Kegiatan 
Sesi kedua, pemateri menjelaskan standar yang berlaku dalam menyusun laporan keuangan desa. Pada sesi ini peserta dijelaskan standar akuntansi keuangan sektor publik. Sesi ketiga, peserta diberikan penjelasan cara mencatat jurnal ketika ada transaksi. Selin itu peserta juga diberikan contoh kasus dan cara membuat jurnalnya serta memposting kedalam buku besar. Sesi kelima, pada sesi ini diisi dengan tanya jawab antara tim pengabdian dengan para pengelola keuangan desa. Para peserta diberikan waktu 30 menit untuk berdiskusi serta menyampaikan kesulitan yang dialami. Sesi keenam, mempraktikan membuat laporan keuangan desa sesuai dengan standar yang berlaku. Peserta membuat laporan keuangan desa dan tim pengabdi memantau serta membantu jika ada kesulitan yang dialami peserta.

Hal yang menjadi catatan adalah pentingnya kerjasama antara institusi dengan desa binaan, karena untuk jangka panjangnya tidak hanya pelatihan saja tetapi pendampingan secara berkala.Keberhasilan program pelatihan ini diukur dengan parameter:

1. Melakukan input data transaksi hingga mampu menyusun laporan keuangan

2. Meningkatnya kualitas informasi bagi masyarakat sebagai dasar evaluasi kinerja perangkat desa.

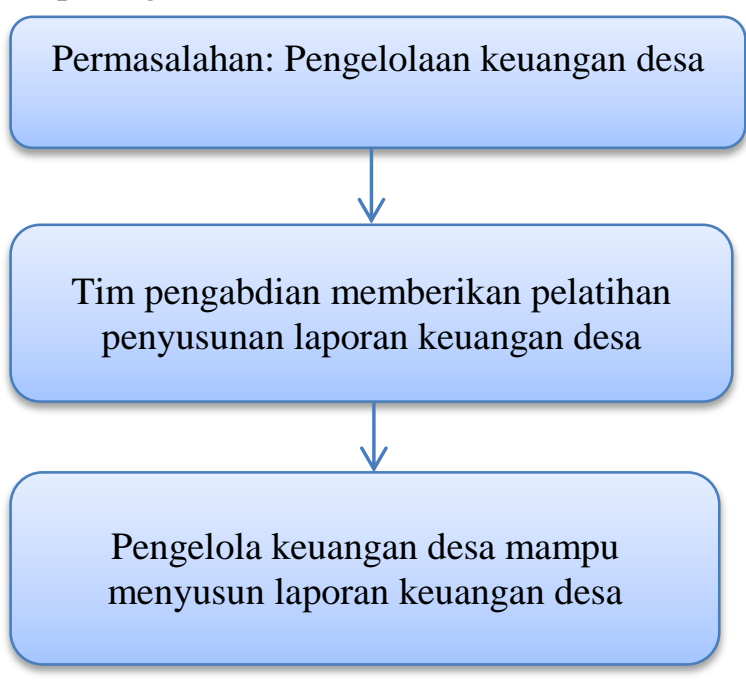

Gambar 2. Bagan Keberhasilan Pelatihan

\section{KESIMPULAN}

Kesimpulan dari kegiatan pelatihan pengelolaan keuangan desa di Desa Mlandi, Kecamatan Garung, Wonosobo yaitu:

- Bagi pengelola keuangan desa, kegiatan ini merupakan pengenalan awal tentang standar akuntansi sektor publik dan mekanisme pengelolaan keuangan desa.
- Bagi perangkat desa, mendapatkan pengetahuan tentang pengelolaan dokumen khususnya dokumen dalam penyusunan laporan keuangan desa.

- Bagi masyarakat Desa Mlandi, memperoleh pengetahuan tentang laporan keuangan desa sehingga masyarakat mampu memahami cara membaca laporan keuangan desa sebagai salah satu bentuk akuntabilitas perangkat desa.

\section{UCAPAN TERIMA KASIH}

Terima kasih kepada SMK Bhinneka Karawang yang telah membantu dan berkontribusi di dalam kegiatan pengabdian kepada masyarakat ini.

\section{DAFTAR PUSTAKA}

Astini, Y., Fauzi, Agus, K., \& Widowati. 2019. Detreminan yang Mempengaruhi Keberhasilan Pengelolaan Keuangan Desa. Valid Jurnal Ilmiah. Vol 16(1). 29-47 pp.

Diansari, R. E. 2015. Analisa Implementasi Alokasi Dana Desa (ADD) Kasus Seluruh Desa Di Kecamatan Kledung Kabupaten Temanggung Tahun 2013. Prosiding Seminar Nasional Universitas PGRI Yogyakarta. 504-511 pp.

Hanifah, S. I., \& Praptoyo, S. 2015. Akuntabilitas Transparansi Pertanggung jawaban Anggaran Pendapatan Belanja Desa (APBDes). Jurnal Ilmu \& Riset Akuntansi. Vol 4 (8).

Husna, S., \& Abdullah, S. 2016. Kesiapan Aparatur Desa Dalam Pelaksanaan Pengelolaan Keuangan Desa Secara Akuntabilitas Sesuai Undang-Undang Nomor 6 Tahun 2014 Tentang Desa ( Studi pada Beberapa Desa di Kabupaten Pidie ). Jurnal Ilmiah Mahasiswa Ekonomi Akuntansi (JIMEKA). Vol 1 (1). 282-293 pp.

Istiqomah, S. 2015. Efektivitas Kinerja Badan Permusyawaratan Desa dalam Meningkatkan Akuntabilitas Pengelolaan Keuangan Desa. Kebijakan Dan Manajelem Publik. Vol 3(1).

Kholmi, M. 2016. Akuntabilitas Pengelolaan Alokasi Dana Desa: Studi di Desa Kedungbetik Kecamatan Kesamben Kabupaten Jombang. Journal of Innovation 
in Business and Economics. Vol 7(2). 143$152 \mathrm{pp}$.

Mardiasmo, 2002. Otonomi dan Manajemen Keuangan Daerah. Penerbit Andi Yogyakarta

Pratiwi, D. N., \& Pravasanti, Y. A. 2020. Analisis Penggunaan Siskeudes dalam Pengelolaan Dana Desa. Jurnal Akuntansi dan Pajak. Vol 20 (2). 217-223 pp.

Wida, S. A., Supatmoko, D., \& Kurrohman, T. 2017. Akuntabilitas Pengelolaan Alokasi Dana Desa (ADD) di Desa - Desa Kecamatan Rogojampi Kabupaten Banyuwangi. E-Journal Ekonomi Bisnis dan Akuntansi. Vol 4 (2). 148-152 pp. 